\title{
A microscope for subtle movements in clinical neurology
}

回 Supplemental data
at Neurology.org
Discerning subtle abnormal movements is often critical in making the correct neurologic diagnosis. However, many telltale movements are hardly visible to the nonspecialist's eye. Using Eulerian video magnification (EVM), which applies a spatial and temporal filtering algorithm to amplify movements digitally on (real-time) video, ${ }^{1}$ we present 3 neurologic patients in whom the diagnosis became obvious after video magnification (video on the Neurology ${ }^{\circledR}$ Web site at Neurology.org): idiopathic Parkinson disease, with a subtle asymmetric resting hand tremor; orthostatic tremor of the legs; and an inconspicuous generalized epileptic seizure. These cases suggest that EVM could be employed as a "microscope" for assessing or monitoring subtle abnormal movements.

Nasir A. Aziz, MD, PhD, Martijn R. Tannemaat, MD, PhD

From Leiden University Medical Center, the Netherlands.

Author contributions: Nasir Ahmad Aziz: drafting/revising the manuscript, study concept or design, analysis or interpretation of data, accepts responsibility for conduct of research and final approval, acquisition of data, study supervision. Martijn R. Tannemaat: drafting/ revising the manuscript, analysis or interpretation of data, accepts responsibility for conduct of research and final approval.

Study funding: No targeted funding reported.

Disclosure: The authors report no disclosures relevant to the manuscript. Go to Neurology.org for full disclosures.

Correspondence to Dr.Aziz: n.a.aziz@lumc.nl

1. Eulerian. Video magnification. Available at: http://people.csail.mit.edu/mrub/vidmag/. Accessed April 10, 2015.

\section{WriteClick ${ }^{\circledR}$ rapid online correspondence}

The editors encourage comments about recent articles through WriteClick:

Go to Neurology.org and click on the "WriteClick" tab at the top of the page. Responses will be posted within 72 hours of submission.

Before using WriteClick, remember the following:

- WriteClick is restricted to comments about studies published in Neurology within the last eight weeks

- Read previously posted comments; redundant comments will not be posted

- Your submission must be 200 words or less and have a maximum of five references; reference one must be the article on which you are commenting

- You can include a maximum of five authors (including yourself) 


\title{
Neurology
}

\author{
A microscope for subtle movements in clinical neurology \\ Nasir A. Aziz and Martijn R. Tannemaat \\ Neurology 2015;85;920 \\ DOI 10.1212/WNL.0000000000001914
}

This information is current as of September 7, 2015

\section{Updated Information \& Services \\ Supplementary Material \\ Subspecialty Collections}

Permissions \& Licensing

Reprints including high resolution figures, can be found at: http://n.neurology.org/content/85/10/920.full

Supplementary material can be found at: http://n.neurology.org/content/suppl/2015/09/05/WNL.0000000000001 914.DC1

This article, along with others on similar topics, appears in the following collection(s):

Clinical neurology examination

http://n.neurology.org/cgi/collection/clinical_neurology_examination Parkinson's disease/Parkinsonism http://n.neurology.org/cgi/collection/parkinsons_disease_parkinsonism Tremor

http://n.neurology.org/cgi/collection/tremor

Video/ EEG use in epilepsy

http://n.neurology.org/cgi/collection/video_eeg_use_in_epilepsy

Information about reproducing this article in parts (figures,tables) or in its entirety can be found online at:

http://www.neurology.org/about/about_the_journal\#permissions

Information about ordering reprints can be found online:

http://n.neurology.org/subscribers/advertise

Neurology ${ }^{\circledR}$ is the official journal of the American Academy of Neurology. Published continuously since 1951, it is now a weekly with 48 issues per year. Copyright () 2015 American Academy of Neurology. All rights reserved. Print ISSN: 0028-3878. Online ISSN: 1526-632X.

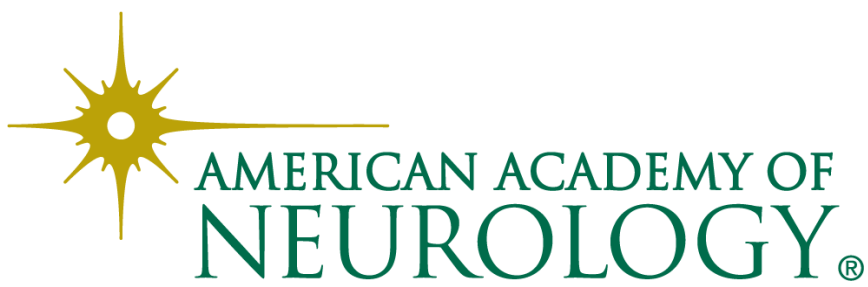

